ISSN 2414-1143

Научный альманах стран Причерноморья. 2019. Том 17. № 1

DOI 10.23947/2414-1143-2019-17-1-33-40

UDC 393.1(470.67)

\title{
TRADITIONS AND CUSTOMS OF THE PEOPLES OF DAGESTAN (HISTORICAL AND CULTURAL ANALYSIS OF FUNERAL RITES)
}

\author{
(c) Sarat G. Hiyasova, Maida G. Mustafaeva, Farid M. Mustafaev \\ Dagestan State Pedagogical University, Makhachkala, Russia \\ science-almanac@mail.ru
}

The article is devoted to a comprehensive historical and cultural research of funeral rites as an important part of traditional Dagestan culture. The funeral rites of the peoples of Dagestan are the most well established and "consecrated" by the ancient traditions cycle of actions, the violation of which has met and still meets with strong condemnation from public opinion. It reflects the moral attitudes developed by a long experience of national life. Despite the deeply tragic nature of the process itself, there is a clear regulation of ritual activities, there are elements of theatricality. The entire cycle of the early funeral rites of the people of Dagestan is analyzed, which includes pre-funeral customs and rituals, funerals themselves and rites and customs associated with funerals. A comparative characteristic with the funeral rite at the present stage is also carried out; its current and obsolete elements are indicated. The authors come to the conclusion that the funeral ritual of the Dagestan peoples was and re-mains multi-layered, despite the greatest Islamization and regulation by the clergy of many moments of the funeral cycle. It is shown that many elements of the former pagan rituals have been preserved and reflected in the funeral rites, although in a somewhat transformed and modified form.

Keywords: traditions, customs, ceremonies, culture, Dagestan, funeral.

\section{[С.Г. Хиясова, М.Г. Мустафаева, Ф.М. Мустафаев Традиции и обычаи народов Дагестана (исто- рико-культурологический анализ похоронной обрядности)]}

Статья посвящена комплексному историко-культурологическому исследованию похоронной обрядности как важной составной части традиционной дагестанской культуры. Похоронная обрядность народов Дагестана - это наиболее устоявшийся и «освященный» древними традициями цикл действий, нарушение которых встречало и до сих пор встречает резкое осуждение со стороны общественного мнения. Здесь отражены моральные установки, выработанные долгим опытом народной жизни. Несмотря на глубоко трагический характер самого процесса, имеет место четкая регламентация обрядовых действий, присутствуют элементы театрализованности. Анализируется весь цикл ранней похоронной обрядности народов Дагестана, включающий в себя предпогребальные обычаи и обряды, собственно похороны и обряды и обычаи, связанные с поминками. Также проводится сравнительная характеристика с похоронной обрядностью на современном этапе, указываются его актуальные сегодня и устаревшие элементы. Авторы приходят к выводу, что похоронный ритуал дагестанских народов был и остается многослойным, несмотря на наибольшую исламизированность и регламентацию духовенством многих моментов похоронного цикла. Показано, что в похоронной обрядности сохранились и отразились многие элементы былой языческой обрядности, хотя в несколько трансформированном и измененном виде.

Ключевые слова: традиции, обычаи, обряды, культура, Дагестан, похороны.

Sarat G. Hiyasova - candidate of pedagogic sciences, associate professor. Dagestan State Pedagogical University, Makhachkala, Russia.

Maida G. Mustafaeva - doctor of philosophy, professor. Dagestan State Pedagogical University, Makhachkala, Russia.

Farid M. Mustafaev - doctor of philosophy, associate professor. Dagestan State Pedagogical University, Makhachkala, Russia.

Хиясова Сарат Гасановна - кандидат педагогических наук, доцент. Дагестанский государственный педагогический университет. г. Махачкала, Россия.

Мустафраева Маида Ганифаевна - доктор фрилософрских наук, профрессор. Дагестанский государственный педагогический университет. г. Махачкала, Россия. 
Мустафраев Фарид Мустафраевич - доктор философрских наук, доцент, Дагестанский государственный педагогический университет, г. Махачкала, Россия.

Dagestan is a land of out-and-outer and original culture, with a huge variety of unique traditions and customs. In this article, we would like to reveal one of the sides of social culture, on the example of the funeral rituals of the peoples of Dagestan. Since it is believed that the funeral rites are the most well-established sphere of ritual life and the most Islamized of all spheres of family life.

In fact, this is far from the case, since many of the elements were not so much Islamized as they were dressed in a religious dress. At the same time a considerable part of the funeral rites, has deep roots and dates back to the era of pagan beliefs. In essence, this is the most established and "consecrated" by ancient traditions cycle of actions, the violation of which has met and still meets with harsh condemnation of those around them. It reflects the moral attitudes developed by a long experience of national life. This dictated a clear regulation of ritual actions, their moments, order, which, despite the deeply tragic nature of the process, created elements of theatricality in it.

The cycle of funeral and memorial rites can be divided into three stages: pre-funeral customs and rites, the actual funeral and rites, and customs associated with funerals.

The death of a person is a kind of phenomenon that is inevitable for each person and at the same time, a large number of people perceive it as something far away, something that will not happen very soon. At the same time, the people have preserved a lot of beliefs, according to which people single out for themselves certain death omens, such as certain dreams of the patient or his relatives, perceived by them as prophetic (for example, the vision of a dead relative, loss of the molar tooth, fire), the appearance of cracks in the house on the wall or in the ceiling. About the imminent approach of the death of their relative, they were usually guessed by the sallow complexion, a special spot on it, by colourless, dim eyes. If the patient has not yet had time to make a will (vasiyat, nazra), they hinted at it, and if possible, with the witnesses, they tried to write down the patient's orders, in order to avoid conflicts between the families. All this is still preserved in the traditional culture; this is especially important for the countryside of Dagestan. The relevance of this phenomenon (the presence of a will) is largely due to the regulation of this custom by Islam. During life, in many rural societies, elderly people wrote a testament in two copies, one was kept in a mosque. At the same time, they did not forget to al-locate a certain share of the mosque (majlis sadak).

There were usually close relatives at the bedside of the dying person. They also called the mullah, who read the prayer of parting "Yasin" until his dying breath [5, p. 348-352]. After death, he supported his chin and tied up his jaw, lined it up, closed his mouth and eyes. Immediately a man was appointed who was supposed to put him down in the grave. Today, as in the old days of Dagestan, many elderly people specially prepare everything necessary for the funeral themselves: they buy a shroud, sew a long shirt from coarse calico, some can be knotted from the bottom; a scarf and a veil are prepared (preferably green).

During the agony, others were forbidden to shout, make noise (according to beliefs, it was considered that the "departing soul" might lose its way), only the mullah read the requiem in a low voice. If earlier, it was prescribed to con-sider death calmly as a systematic transition of the soul to another world, while death was considered the beginning of a new life, then today it is supposed to meet death calmly, as God's inevitable foreshadowing. It is interesting to note that even with regard to death, the concepts of "good and bad days" are preserved in the ideas of Dagestanis, for example, they said and say that only pious people die on Friday morning or on the days of the annual fast (Uraza), these days, it was thought, the gates of Paradise were widely open. There were ideas that if it rains on the day of the 
funeral, all living things around are crying and asking Allah for the forgiveness of the sins of the deceased.

The dead person was laid on the mattress in the middle of the room so that his face was oriented to the south-west, i.e. towards Mecca. The deceased person was first washed with the observance of the intended ritual; woman washed woman, man washed man. Often three people washed the dead man: one washed, the other watered, and the third one provided the things needed. Moreover, the water for washing was supposed to be taken from the river downstream, and not upstream, as usual. In some villages of Dagestan, the clothes of the departed went to those who washed him.

Water after washing should be poured into a clean place, while ensuring that no one took the water for himself or herself and did not use it for various magical acts. Then the preparation of the body began: the deceased was sur-rounded by fragrant grass (walnut) wrapped in a clean piece of cloth; parts of the body (head, both palms, knee bends, both feet) were covered with clean small pieces of cloth, and all the holes on the human body (nostrils, mouth, etc.) were blocked. Hair was combed and carefully laid by the ears. Aged women were combed under the right cheek, and the young deceased were braided (this representation has practically not survived). Then they were put on a prepared shirt, knotted it from the bottom with a knot (like a bag), tied a scarf, and then wrapped the dead person from head to toe in a shroud.

On top of the shroud, the body was wrapped with a rope, with which the dead person was measured, and then the man was covered with a black burka, and the woman was covered with material, preferably a bottle-green color. A metal object (dagger, knife, etc.) was put on top of the abdominal area of the deceased in order not to have a swollen belly, although of course this was a magical device common to the peoples of the North Caucasus, associated with the idea that metal things scare away evil spirits [4. with. 85].

The funeral procedure itself in the Dagestan societies required the presence of an organizer, usually an experienced person who could do this was appointed to supervise the funeral. All relatives were notified of death. Earlier, when there were no means of communication, messengers (chapars) were sent to different villages, who were supposed to notify the kunaks. The fact that chapar brought the sad news was recognized by his lowered head and sad look. All, leaving the job, they hurried to the house of the deceased to express their condolences. Even from midnight, if a person died at night, having heard woeful cries, neighbors and relatives immediately resorted. Having learned about the grief that had happened, everyone hurried to express their condolences, which the older man from close relatives usually listened to. Great collective co-participation, a certain solidarity of relatives, acquaintances, neighbors and today is a characteristic feature of the funeral rites of the peoples of Dagestan.

In the house of the deceased, men and women gathered to share grief with his or her family, to provide all possible assistance in the device of the funeral. The higher the social status and authority of the deceased, the more people came to the funeral from neighboring villages and societies.

Jamaat formed tazyat - the mourning meeting of men in the yard of the deceased. Men, relatives of the deceased, were located in the courtyard, standing in one row with their backs to the wall of the house, with their faces facing the yard; older men could sit, but when a person came, they would get up. Each of the newly arrived men approached the jamaat, read the prayer Fatihla (Koran, Suza 1), which the others present also started reading together. Then he approached the elder man of the family (tukhum), uttered words of participation expressing sympathy, and shook hands with all. At the very door stood the young and closest relatives of the departed (sons, brothers, etc.), one of whom usually accompanied with crying to the house of the newly arrived man who wished to mourn the deceased in the room of women. The condolence from the men (jamaat) could also be accepted by the sen- 
ior woman, who was specifically asked to go outside to the jamaat. The expressing condolences approached, uttered the requiem prayer "Dug'a", then greeted the hands and said something like this: "What can we do? Allah took him. Let years of life on this earth, meant for him, but not lived by him, will get to those who are near. Let all his sins be washed away." Arrived at the condolences were thanked.

Women went to the house of the deceased, most often gathering (2-3 or more people). Without stopping in the courtyard, they entered the room where the relatives of the deceased were already sitting, hugging them and crying, then sitting down there. It should be noted that this preparatory part of the funeral rites has not undergone major changes up to date.

For some peoples of Dagestan, for example, a part of the Kumyks, on the first night after the death of a person in a circle of close women, there was a distribution of places where one or another relative should sit. The paternal side occupied more honourable place, at ("orta bagan") the central pillar of the house, symbolizing the support of the home hearth, the family, sat down along one senior woman from the paternal and maternal sides. At the wall, relatives from the father's side sat against the door, then from the maternal side; in some societies, two sisters did not sit next to each other. According to the harsh customs of the Kumyks, the father and even the mother of the deceased should have shown great restraint, their external expression of pain, weakness was condemned. On the contrary, the sisters and brothers of the deceased expressed their experiences extremely emotionally, which in some cases reached unbridled self-torture. A little bit easing, this was manifested by his wife, cousins, sisters, etc. It should be noted that the behavior in this situation of each people of Dagestan was regulated, and to this day, they are determined by their customs. Thus, the expression of grief among men - Avars, Dargins, Laks was very restrained, it was not supposed to cry even for their parents, they condemned men for tears. The male relatives lined up in a semicircle, pulling the hats low. The first were the closest ones, if it is an elderly man or woman, then their brothers, then sons (over 15 years old); if it was the untimely death of a young man or girl, then the father, brothers, uncles from the paternal and maternal side. Men of the southern part of Dagestan, the Kumyks, on the other hand, have a very emotional expression, often with a loud cry of grief.

As a rule, with each newly arrived woman a collective cry began. The mourning was especially intensified when, with the condolences of each new group, outsiders appeared, and often men. The more respected the newly arrived guest was the more strongly expressed the feeling of grief in their lamenting of the relative of her deceased (deceased). Close acquaintances also had to mourn the deceased with traditional or improvised lamentations as a sign of sympathy. Friendship, consecrated friendship of the people was considered and is considered not lower than the kinship, and therefore the friends of the deceased could express their grief also very emotionally, like close relatives, even crying and selftorturing.

Thus, during the whole time while the body was being prepared for the funeral, there was a cry in the house. Mass mourning of the deceased was carried out for 5-7 days. The women mourned the deceased in a special room. It is significant that the younger the dead was, the closer relatives tortured themselves, tore at their clothes, scratched their faces, ruffled their hair, etc. At the present stage, including due to the strengthening of religious selfconsciousness, this custom has undergone changes, since such tortures are not shared by Islamic tradition, since the precepts of Islam and Shariah condemned the stormy manifestation of grief (as if opposing the will of Allah too vehemently expresses its protest about this).

P. Przhetslavsky painted the picture of mourning of the deceased, typical of many peoples of Dagestan, he wrote: "The closest relatives with disheveled hair and shirt lowered to the waist or dressed in coolies with holes for a head and hands, pounding themselves more than others and crying improvise a song praising the merits of the deceased" [3, p. 290]. He 
further reports that the wife at the funeral should cut off the braids. In many societies, a widow was sup-posed to shave. A similar ceremony was known to many peoples of Dagestan [3, p. 295].

The expression of condolences for women consisted in the fact that they alternately approached the closest relatives with a loud cry, embracing and saying approximately: "What did he (she) do? Why did he (she) leave us? O Allah, look what he did! What do you say to that? Was it bad for him to be with us!" etc.

The crying reached its apogee when one of the close relatives came out into the circle and began to lament loudly in rhyme, talking about the miserable share of the deceased left, about his merits, moral qualities. In general, songs of lamentation are this unique monument of folk art, the history of which dates back to the depth of centuries, characteristic of the funeral ritual ceremony of all the peoples of Dagestan. Samples of the funeral poetry of the peoples of Dagestan are given in S. Sh. Gadzhiyeva "Family and marriage among the peoples of Dagestan in the 19th and early 20th centuries" [1, p. 202-203]. Songs of lament were different expressions of grief for the deceased. The greatest expressiveness was the lament for the untimely bygone young people (for the bride, for the groom). A special place was occupied by the mother and cry for a son or daughter. As a rule, the laments represented with themselves a lamentation - appeals (babali, chazin - mother's, dear, etc.) to the deceased himself.

It is believed that, at an early stage, the crying was looked more likely not only as an expression of grief, but also as a form of communication with the deceased, and in general with the inhabitants of the other world. In the crying, there was basically a kind of dialogue in which, on the one hand, they had to report the dead, and at the same time convey news of the living to their long-dead relatives.

It was supposed to bury the deceased the same day, if death came in the morning or afternoon, and if in the evening they were buried the next day, since ancient times it was believed that the realm of the dead closes after sunset. Sometimes it was decided to bury on the verge of sunset. In antiquity, it was believed that the soul of a dead man would be treated in heaven as an evening guest, they would accept him well and not offend him. However, in fact, such requirements for the burial were made by Islam.

The body was laid on a stretcher, at this time (although the clergy did not approve) the aunt and sister could come and, having covered the dead man with some cloth, quietly say in the ear a name of a long-dead relative. According to ancient beliefs, it was thought that through the deceased one could transfer something to another (to that world). This rite was also resorted to, if anyone had a dream of a long-dead relative in worn clothing or without it. Then the closest people from the men carried the body headfirst. This was supposedly done so that the dead man did not come back and did not take anyone with him.

They stopped outside, and before the crowd of fellow villagers lined up in two crowds (men and women). One of his relatives spoke several words de-scribing the deceased (whether he had debts, whether he left a will, what kind of person he was for family, neighbors, friends and relatives, etc.) As a rule, relatives should pay debts (by will or without it) before the funeral, if there was a possibility, if there was no such possibility, they set a payment term. They tried to speak only good things about the dead man. If a person was known for improper acts during his life and did not follow the instructions of Islam, then when stopped, they did not say anything about such a person. It is no coincidence that when people want to say badly about a person, they say: "He is one of those about whom they will not say anything even after death."

During this stop, someone handed out to those present (a woman among women, a man among men) $1 / 4$ of the bread. Then the closest people were al-lowed to look at the dead man for the last time, but at the same time, the stretcher was not put on the ground. The women went to the house, where they immediately sat down in a semicircle and began 
to read various prayers (zikr), the men went to the cemetery. In some societies, after the removal of the body, it was necessary to clean the floor and walls $(1.5 \mathrm{~m})$ and pour out all the water in the house. At an early stage, a number of peoples at the first night after the death of a man whitened walls of his room, because they believed that Azrael (the angel of death), taking a soul, cuts a man's throat with a knife and blood splatter walls. If there was water in the jugs in this room, then they did not use it for anything, they poured it out, because, according to legends, there could also have been the blood of the deceased. For 40 days in the room of the de-ceased they left a lit light, since according to some beliefs, it was believed that in these days the spirit of peace comes and monitors the kind of respect that is given to those close to his memory.

Bread with pieces of raw fat tail (kurduk), baked tortillas with cheese, handed out to everyone who was present at the burial, and were brought from the house of the dead man to the cemetery. After sadak, one of the elders read "duga", all but close relatives got up and left. Next to the gravestone, they made a tent of felt for someone who had to read the Karan during the week (for the wealthy - for 40 days), staying overnight. Every day, three times during the week - (in the morning and in the evening at the cemetery and during the day at the house of the deceased) the men gathered for prayer (qulgiu). In the evening, in the house of the deceased, also for 7 days, women gathered for ecstatic prayers with chants (zikr). As a rule, all the participants were treated with lumps of roasted barley flour mixed in butter, a chudu (among Avars), baked cheesecakes and flour halva (among Kumyks, Laks, a part of Dargins).

It should be noted that although the official mourning was supposed to be worn only for a week, many women did not follow this order and wore mourning for 40 days, or even a whole year or more, if the deceased was young. Mourning was supposed to be worn by all relatives for no more than 7 days. In the traditional culture of Dagestan, it consisted in the fact that all men did not shave; women in highland societies wore black dyed dresses and lowered the ends of their scarves, tied them up under their chins. On the seventh day, the closest relative was to shave his beard and thereby give the opportunity to remove the mourning for the rest. Mourning for the widow was 4 months and 10 days. Some Avarians made young widows have their heads shaved (what was done with the hair is unknown). Perhaps this is a transformed ritual of cutting off the braid, which was observed by many nations, and apparently could be a relic of the once-existing sacrifice of the widow of the deceased. A young widow was also brought a sheepskin coat with cropped false sleeves; her parents gave her a mourning dress, and if there were none, aunts. Sheep-skin fur coats were used as mourning clothes by many nations, in this custom there was a desire to scare away, to deceive malicious evil forces. A number of Kumyks in the funeral rite had developed both the color symbolism of the clothes, which in a different way reflected both the degree of closeness of a person to a dead person and the time passed since his death.

Therefore, the sisters and wife wore black dresses and white scarves. Cousins and second cousins wore gray, mouse-colored dresses. For the wife and sister there were two periods of mourning: two years they wore black clothes, five or six months after that - gray.

It is important to note that the funeral rites of Dagestan in the early stages were much more austere and at the same time much theatrical than at the present stage. For example, in antiquity, self-torture, self-flagellation, asceticism occupied a significant place in the funeral rite of Kumykovs. Women scratched themselves, cut faces with glass. The sisters cut off the braids, tore them, and wrapped around the wrist in the form of a bracelet. Both women and men committed some ancient ritual (shahalay), when barefoot, even in winter men went to the cemetery, and the closest relatives, as reported by re-sources, happened to go there in the winter, for forty days in the snow. Both in summer and in winter, close relatives and relatives of the deceased did not take off their outer clothing, belts, and arms even at night; the wife could sleep for years in top clothes on felt, and not in bed, live in a dark room. 
Women did not wash their heads, did not bathe, and did not comb their hair for 40 days. The sisters of the deceased had been sitting in a dark room for a year, or more, and had not given birth for two or three years. Lifestyles were discreet, they did not appear in society for a long time, and later, when they came out, they spoke little, did not sit in places of honor, etc.

For three days during the season of agricultural work and for a week at another time, fellow villagers did not go out with their relatives to work in the field. On the seventh day, there were large commemorations or, as they were called, a "big prayer" with the participation of a large number of people (at least 70 people), depending on the size of the tukhum, given to sadak (alms). The size of this donation for the soul of the deceased depended on the wealth of the family; it could be unit pieces of meat, chicken, duck, etc.

The main part of a wake was completed with the removal of the tent in the cemetery. Commemorations were held on the 30th or 40th or 52th day (it was believed that on the 52 nd day the bones were separated from the meat), although the clergy did not officially approve of them, due to the lack of information in Islam in this regard. The dead were commemorated every Thursday evening and on Friday from $11 \mathrm{am}$ to $2 \mathrm{pm}$, they believed that it was at this time that the souls who died left the grave and received what was given out as a sadak (alms). It could be pieces of bread, tortillas, boiled corn, various sweets, and flour halva.

At the end of the year after the funeral, the official commemorations were arranged. On this day, many people gathered for zikr - collective prayers, where men and women were located separately, at the end of which sadakas were distributed (tortillas with cheese, chudu, pieces of fat chicken with bread); for the poorest layers the main memorial food were oatmeal lumps (gudu).

A huge number of people-relatives, fellow villagers, and kunaks were gathering for a big wake. In spite of the fact that relatives and all the gathered women brought what they could (usually a flour measure, a little butter, cheese), the funeral was a heavy burden on the family's shoulders, especially if the deceased had children. It should be noted that at the present stage the funeral in Dagestan is a very burdensome procedure for the family of the deceased, provided that the basis of their organization are the traditions and customs of Dagestan. For example, in addition to the very richly and generously furnished tables of various dishes that are laid today on the occasion of a commemoration in Dagestan, everyone who came to the condolence as charity is given food packages - sadaka (rice, tea, oil, etc.).

As a rule, both Dagestan villages and cities had and have their own cemeteries located near the village. At the end of the year (for rich people 40 days), instead of a temporary gravestone stone, a monument was erected, a stele with different quotations from the Karan, inscriptions with the date of death and the name of the deceased. The view of the monument depended on the material and social status of the family of the deceased. In some villages, the steles differed depending on the sex that was buried (for men, the top looked like a turban, and for women it was a rectangle). Avarians believed that the flag of cloth (white, blue or green) on the grave, swinging in the wind, "reads the prayer", and this in turn washes away sins, therefore it is not by chance that for older people (as they have lived more and more sins they have) on the graves at the head of the stele from one to three flags on a wooden pole were stuck.

In general, the complex of commemoration rituals of the peoples of Dagestan, which is firmly entrenched in the traditional culture of Dagestan and has not lost its relevance, and today is seen as a remnant cult of deceased ancestors. This is the cult where the living, in response to their ritual acts, expected from their dead ancestors support in their affairs. Here one can also see some kind of compensatory function, when a person did not have time to give to a close person, relative enough attention during life, and tries to compensate for the loss after his death through alms, commemoration, etc. 
At the present stage, this ritual is a stumbling block and cause of numerous disputes and discussions in Dagestan between supporters of the early traditions and customs of the ancestors and some of the deeply religious people who see pagan roots in this rite. In many respects, commemoration ceremonies were performed and by virtue of certain remnant convictions, for example, that the soul of the deceased every Thursday and Friday, during religious holidays, comes into the house and watches how they remember it. They thought that if not to propitiate it, it would feel bad and the soul would curse the household or, even worse, make revenge.

Thus, we see that the funeral ritual of the Dagestan peoples was and remains multilayered, despite the greatest Islamization and regulation by the clergy of many moments of the funeral cycle. In funeral rites, many elements of the past pagan rituals are preserved and reflected, though in a somewhat trans-formed form (transmission of presents through the deceased, young widow's shaving during mourning, flags at the cemetery, Fridays sadak at the cemetery, and many other things).

\section{Лumepamypa}

1. Гаджиева С.Ш. Семья и брак у народов Дагестана в XIX - начале XX века. М.: Наука. 1985.

2. Мустафраева М.Г., Мустафраев М.В. Вопросы социально-психологического поведения личности: национальные и этноконфессиональные аспекты. Известия Северо-Кавказского научного центра высшей школы. 1987. № 2.

3. Пржелавский П. Нравы и обычаи в Дагестане. Военный сборник. 1960. № 3.

4. Смирнова Я.С. Семья и семейный быт народов Северного Кавказа. М., 1983.

5. Сура 36 Корана. Коран Перевод и комментарии Крачковского. М.: Изд-во Восточной литературы, 1963.

6. Хиясова С.Г. Ранние формы и рудименты в традиционном исламе. Современные исследования социальных проблем. 2016. № 2-1(26).

\section{References}

1. Gadzhiyeva S.SH. Sem'ya i brak u narodov Dagestana v XIX - nachale XX veka. [Family and marriage among the peoples of Dagestan in the XIX - early XX century.]. Moscow. Nauka [Science]. 1985 (In Russian).

2. Mustafayeva M.G., Mustafayev M.V. Voprosy sotsial'no-psikhologicheskogo povedeniya lichnosti: natsional'nyye i etnokonfessional'nyye aspekty. Izvestiya SeveroKavkazskogo nauchnogo tsentra vysshey shkoly. [Issues of socio-psychological behavior of the individual: national and ethnon-confessional aspects. North Caucasus Higher School Research Center Review]. 1987. No. 2 (In Russian).

3. Przhelavskiy P. Nravy i obychai v Dagestane. Voyennyy sbornik. [Customs and customs in Dagestan. Military collection]. 1960. No. 3 (In Russian).

4. Smirnova YA.S. Sem'ya i semeynyy byt narodov Severnogo Kavkaza. [Family and family life of the peoples of the North Caucasus]. Moscow, 1983 (In Russian).

5. Sura 36 Korana. Koran Perevod i kommentarii Krachkovskogo. [Surah 36 of the Karan. Karan Translation and comments of Krachkovsky]. Moscow. Izd-vo Vostochnoy literatury [The publishing house of the East literature] 1963 (In Russian).

6. Khiyasova S.G. Ranniye formy i rudimenty $v$ traditsionnom islame. Sovremennyye issledovaniya sotsial'nykh problem. [Early forms and rudiments in traditional Islam. Modern studies of social problems]. 2016. No. 2-1 (26) (In Russian). 